\title{
Immunohistochemical Characterization of Canine Lymphomas
}

\author{
Roxana CORA, Adrian Florin GAL, Marian TAULESCU, Flaviu TĂBĂRAN, Raluca VIDRIGHINESCU*, Gina \\ Corina TOMA, Cornel CǍTOI
}

Faculty of Veterinary Medicine, University of Agricultural Sciences and Veterinary Medicine, 3-5 Mănăştur Street, 3400 Cluj-Napoca, Romania

* corresponding author: raluca.vidrighinescu@gmail.com

Bulletin UASVM Veterinary Medicine 74(2)/2017

Print ISSN 1843-5270; Electronic ISSN 1843-5378

doi:10.15835/buasvmen-vm:0003

\begin{abstract}
Lymphomas occur by clonal expansion of lymphoid cells and have distinctive morphological and immunophenotypic features. Determination of canine lymphoma immunophenotype is useful for accurate prognosis and further therapy. In the suggested study, we performed an immunohistochemical evaluation of some cases with canine lymphoma diagnosed in the Department of Pathology (Faculty of Veterinary Medicine, ClujNapoca, Romania), in order to characterize them. The investigation included 39 dogs diagnosed with different anatomical forms of lymphoma, following necropsy analysis or assessment of biopsies. The diagnosis of lymphoma was confirmed by necropsy and histopathology (Hematoxylin-eosin stain) examinations. The collected specimens were analyzed by immunohistochemistry technique (automatic method) using the following antibodies: CD3, CD20, CD21 and CD79a. The analyzed neoplasms were characterized as follows: about $64.10 \%$ of cases were diagnosed as B-cell lymphomas, $33.34 \%$ of cases as T-cell lymphomas, whereas $2.56 \%$ of cases were null cell type lymphomas (neither B nor T). Most of multicentric (80\%), mediastinal (60\%) and primary central nervous system lymphomas $(100 \%)$ had B immunophenotype, while the majority of cutaneous $(80 \%)$ and digestive $(100 \%)$ lymphomas had $\mathrm{T}$ immunophenotype. Immunohistochemical description of canine lymphomas can deliver some major details concerning their behavior and malignancy. Additionally, vital prognosis and efficacy of some therapeutic protocols are relying on the immunohistochemical features of canine lymphoma.
\end{abstract}

Keywords: antibody, dog, immunohistochemistry, lymphoma

\section{INTRODUCTION}

Lymphoma is one of the most common malignancies in dogs (Baba and Cătoi, 2007). The annual rate of occurrence varies between 6 and 30 cases per 100,000 dogs (Vonderhaar and Morrison, 2002; Morrison, 2004). Lymphoma accounts for approximately $7 \%$ up to $24 \%$ of all canine neoplasms and about $83 \%$ of all malignant haematopoietic tumors of this species (Valli et al., 2017; Vail et al., 2013). Immunohistochemical examination is used to determine the type of tumoral cells, but this technique may also be useful for the determination of the initial diagnosis (Fournel-Fleury et al., 1997; Vail et al.,
1997; Gibson et al., 2004; Lana et al., 2006; Gelain et al., 2008; Tasca et al., 2009; Comazzi and Gelain, 2011). The immunophenotype of a lymphocyte is identified by determining the expression of specific molecules for B lymphocytes (e.g., CD79a, CD20, CD21), and T lymphocytes (e.g., CD3) (Ponce et al., 2003; Vail et al., 2013). The term null cell is generally used for lymphocytes that have not been immunoreactive for B or T cells. It may be a poorly differentiated cell of unknown origin, or it may be a natural killer cell (NK). We have no antibodies or clear definitions to recognize NK-cell lymphomas in animals, as there is in human medicine (Ponce et al., 2010; Vezzali et al., 2010; Valli et al., 2013). 
Many studies have confirmed that individuals with CD3-immunoreactive lymphoma (i.e., T-type cells) are significantly associated with shorter remission and survival times (Ruslander et al., 1996).

Considering that, in Romania, the imunohistochemical examination of canine lymphomas is rarely performed, we decided opportune to include this technique in our study.

In this paper we performed the immunohistochemical characterization of some canine lymphoma cases diagnosed in the Pathology Department of Veterinary Medicine Faculty, Cluj-Napoca (Romania). Lymphomas were divided according to the immunophenotype into: $\mathrm{B}, \mathrm{T}$ and null lymphomas.

\section{MATERIALS AND METHODS}

In this study were included 39 cases of va rious anatomical forms of canine lymphomas, diagnosed in the Department of Pathology, Faculty of Veterinary Medicine, Cluj-Napoca. The diagnosis of lymphoma was established following the necropsy and histopathology examination. During the necropsy, samples were collected, embedded in paraffin and stained using Hematoxylin-eosin method. The immunohistochemical examination of samples was carried out using the mouse anti- human monoclonal antibodies (Leica Biosystems Newcastle Ltd, United Kingdom): CD3 (clone LN10), CD20 (clone MJ1), CD21 (clone 2G9), and CD79a (clone 11E3). The samples were processed using the automatic Leica Bondmax ${ }^{\mathrm{TM}}$ Immunohistochemistry system (Leica Biosystems Melbourne, Bond Max model, M2 12154 series). Lastly, the obtained samples were counterstained by Mayer's hematoxylin. For all biomarkers applied, the tumoral cells that had the cytoplasmic membrane marked in various levels of brown were considered positive.

\section{RESULTS AND DISCUSSION}

In this study were included dogs with different anatomical forms of lymphoma, most of them were multicentric, followed by mediastinal, cutaneous, digestive and primary central nervous system lymphoma. Immunohistochemical examination results are shown in Table 1.

As can be seen in Figure 1, 64.1\% (25 cases) of all lymphomas had B immunophenotype, 33.34\% (13 cases) were diagnosed with T-phenotype and $2.56 \%$ ( 1 case) were null phenotype (possibly natural killer lymphocytes - NK). No case of lymphoma with mixed phenotype has been identified. According to the literature, between $60 \%$ and $80 \%$ of canine

Tab.1. Immunohistochemical results of the analyzed lymphomas.

\begin{tabular}{llcccccc}
\hline No. & The type of lymphoma & $\begin{array}{c}\text { Number } \\
\text { of cases }\end{array}$ & CD3 & CD20 & CD21 & CD79a & Immunophenotype \\
\hline 1. & Multicentric lymphoma & 20 & - & + & + & + & $\mathrm{B}$ \\
\hline 2. & Multicentric lymphoma & 4 & + & - & - & - & $\mathrm{T}$ \\
\hline 3. & Multicentric lymphoma & 1 & - & - & - & - & $\mathrm{n}$ \\
\hline 4. & Mediastinal lymphoma & 3 & - & + & + & + & $\mathrm{B}$ \\
\hline 5. & Mediastinal lymphoma & 2 & + & - & - & - & $\mathrm{T}$ \\
\hline 6. & Cutaneous lymphoma & 4 & + & - & - & - & $\mathrm{T}$ \\
\hline 7. & Cutaneous lymphoma & 1 & - & + & + & + & $\mathrm{B}$ \\
\hline 8. & Digestive lymphoma & 3 & + & - & - & - & $\mathrm{T}$ \\
\hline 9. & $\begin{array}{l}\text { Primary central nervous } \\
\text { system lymphoma }\end{array}$ & 1 & - & + & + & + \\
\hline
\end{tabular}


lymphomas have B-cell origin, 10\% - 38\% are T-cell lymphomas, about $22 \%$ have both $\mathrm{B}$ and $\mathrm{T}$ phenotype, while null phenotype lymphomas represent less than 5\% (Greenlee et al., 1990; Fournel-Fleury et al., 2002; Wilkerson et al., 2005).

Table 2 summarizes the results of the immunophenotype based on the anatomical distribution of lymphomas included in the study. In the case of the multicentric form, the largest proportion was B-type lymphomas, respectively $80 \%$ (20 cases), followed by $\mathrm{T}$ cell lymphomas $16 \%$ (4 cases) and null type lymphomas $4 \%$ ( 1 case). It seems that other studies also show an incidence of about $80 \%$ of the B phenotype lymphomas (Kiupel et al., 1999).

In Figure 2 (A, B, C and D) we can observe the immunolabelling aspects of multicentric lymphomas with the tested antibodies.
Cutaneous T cell lymphoma had a high incidence, respectively $80 \%$ (4 cases), comparative with cutaneous B cell lymphoma which accounted for $20 \%$ (1 case) of all cutaneous lymphomas. Our results partially correspond to those reported by other authors.

Although cutaneous lymphoma is a heterogeneous neoplasm group including the mycosis fungoides epitheliotrophic form and the non-epitheliotrophic form, most of cutaneous lymphomas show a T cells phenotype (Day, 1995; Fry et al., 2003). Dogs with indolent T-cell cutaneous lymphoma have a longer survival time (Affolter et al., 2009).

In Figure $3 \mathrm{~A}$ and $\mathrm{B}$, it can be seen the positive and negative immunolabelling, in a case of $\mathrm{T}$ cell cutaneous lymphoma.

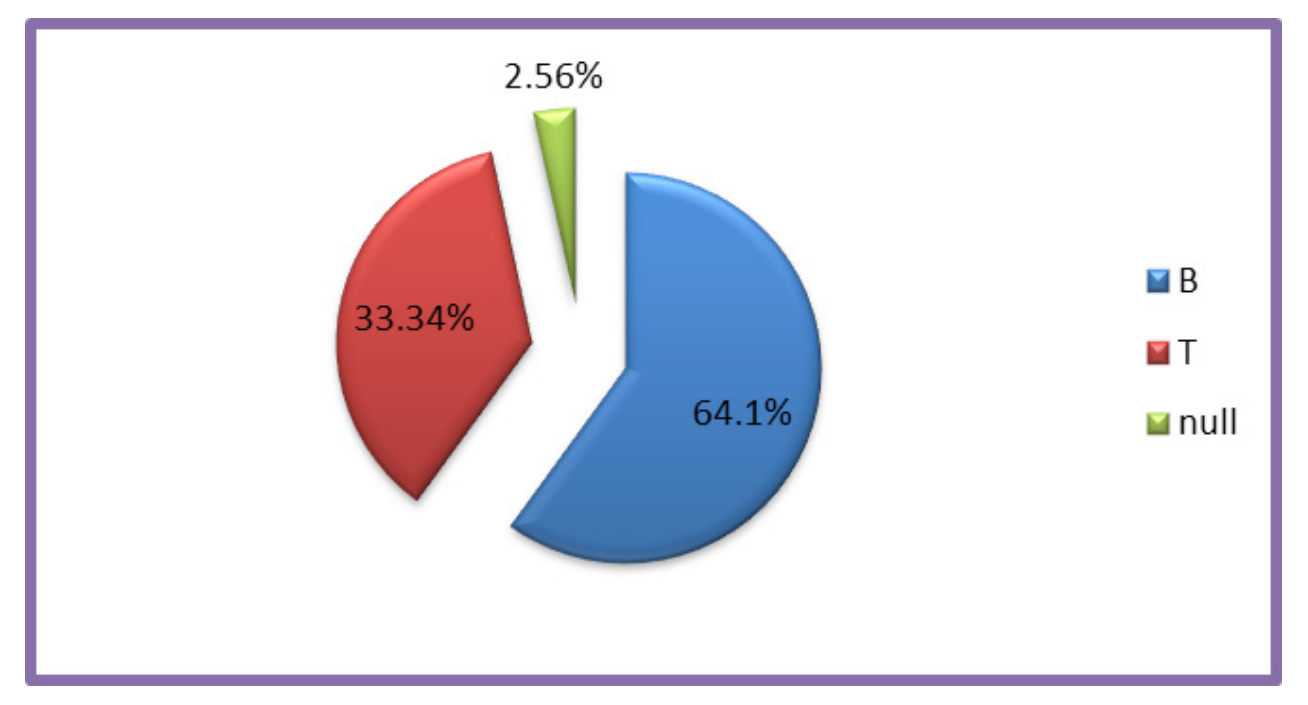

Fig.1. Distribution of lymphomas according to immunophenotype.

Tab. 2: Distribution of lymphoma immunophenotype depending on anatomical form.

\begin{tabular}{|c|c|c|c|c|c|}
\hline Anatomical form & \multirow{2}{*}{ Multicentric } & \multirow{2}{*}{ Mediastinal } & \multirow{2}{*}{ Digestive } & \multirow{2}{*}{ Cutaneous } & \multirow{2}{*}{$\begin{array}{c}\text { Central } \\
\text { nervous } \\
\text { system }\end{array}$} \\
\hline Immunophenotype & & & & & \\
\hline $\mathrm{B}$ & $80 \%(20)^{*}$ & $60 \%(3)$ & $0 \%$ & $20 \%(1)$ & $100 \%(1)$ \\
\hline $\mathrm{T}$ & $16 \%(4)$ & $40 \%(2)$ & $100 \%(3)$ & $80 \%(4)$ & - \\
\hline null & $4 \%(1)$ & - & - & - & - \\
\hline
\end{tabular}

*(the number in brackets refers to the number of cases) 

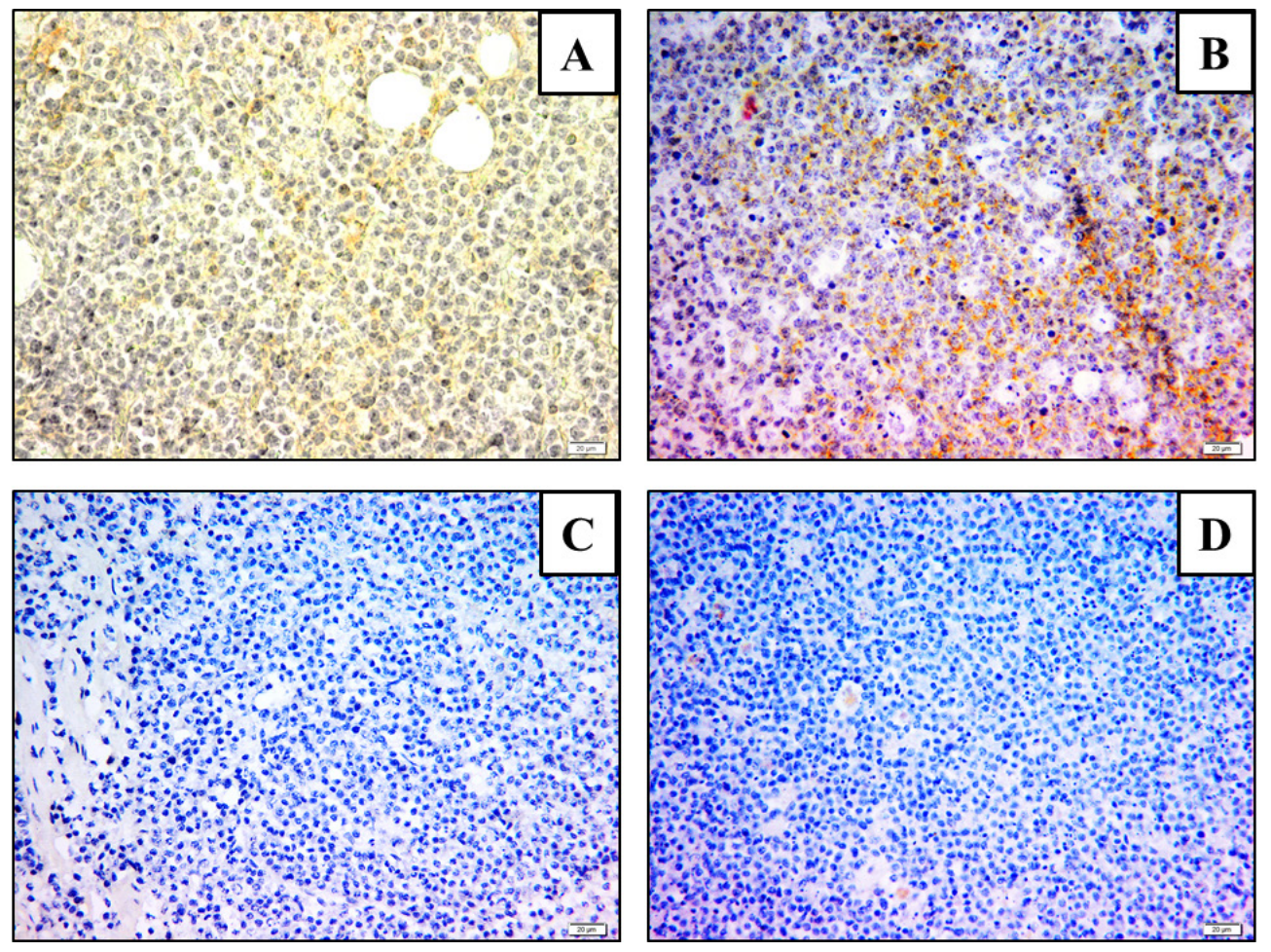

Fig. 2. Immunohistochemical aspects of multicentric lymphoma.

Multicentric B-cell lymphoma: A, B- positive reaction for both CD20 and CD21 antibodies; Multicentric null-type lymphoma: C, D- negative reaction for both CD3 and CD79a antibodies.
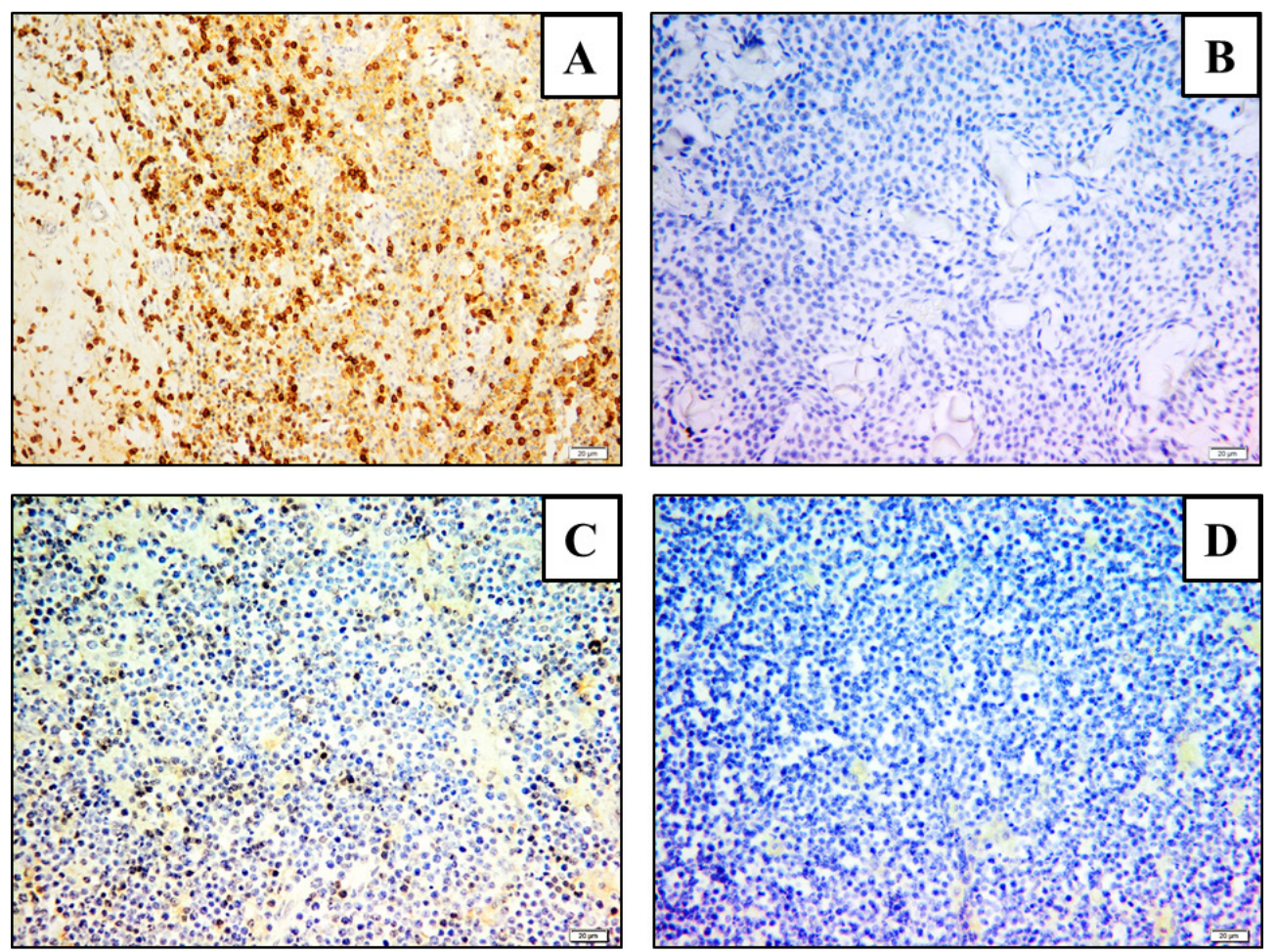

Fig. 3. Immunohistochemical aspects of cutaneous and mediastinal lymphoma.

Cutaneous T-cell lymphoma: A- positive reaction for CD3 antibody, B- negative reaction for CD79a antibody; Mediastinal T-cell lymphoma: C- positive reaction for CD3 antibody, D- negative reaction for CD20 antibody. 
Of all mediastinal lymphomas, $60 \%$ (3 cases) were derived from B lymphocytes, while the remaining $40 \%$ (2 cases) had T-cell origin. These results are not similar to the data presented in other reports. The mediastinal form in dogs is most commonly associated with the T phenotype of tumoral cells (Ruslander et al., 1996; Vail et al., 1996).

Figure 3 (C and D) shows a case of T-type mediastinal lymphoma. Thus, figure $3 \mathrm{C}$ indicates the marking of cytoplasmic membrane for the CD3 antibody, as well as lack of immunlabelling for the CD20 antibody, seen in figure 3D.

The case of primary central nervous system lymphoma was diagnosed with B immunophenotype, being a less common type of extranodal lymphoma in dogs. In a study by Sisó et al. (2017) were included 37 dogs with primary (1 case) and secondary central nervous system lymphoma. About $57 \%$ were B cell lymphomas and $43 \%$ were $\mathrm{T}$ cell lymphomas. The primary central nervous system lymphoma case had B phenotype.

The case of $\mathrm{B}$ cell primary central nervous system lymphoma, shown in figure $4 \mathrm{~A}$ and $\mathrm{B}$, is characterized by the staining of cell membrane for CD79a and CD21 antibodies.

All cases of digestive lymphoma showed $\mathrm{T}$ phenotype. This is correlated with other recent studies suggesting that most digestive tract lymphomas in dogs come from $\mathrm{T}$ lymphocytes and often have epitheliotropism (Coyle and Steinberg, 2004; Ozaki et al., 2006).

In figure $4 \mathrm{C}$ and $4 \mathrm{D}$ is observed a case of digestive lymphoma with $\mathrm{T}$ phenotype, showing a positive reaction for the CD3 antibody, while no immunolabbelling was identified for the CD20 antibody.

Classification of lymphomas according to immunophenotype is of major importance in their therapy and prognosis. Dogs with T-cell lymphoma showed a lower rate of complete chemotherapy response, but also a shorter remission and survival time than dogs with B-cell lymphomas (with the exception of low-grade T-lymphomas) (Teske et al., 1994; Ruslander et al., 1996; Vail et al., 1996). Furthermore, T-cell lymphomas tend to be associated with hypercalcemia (Rosol and Capen, 1992).
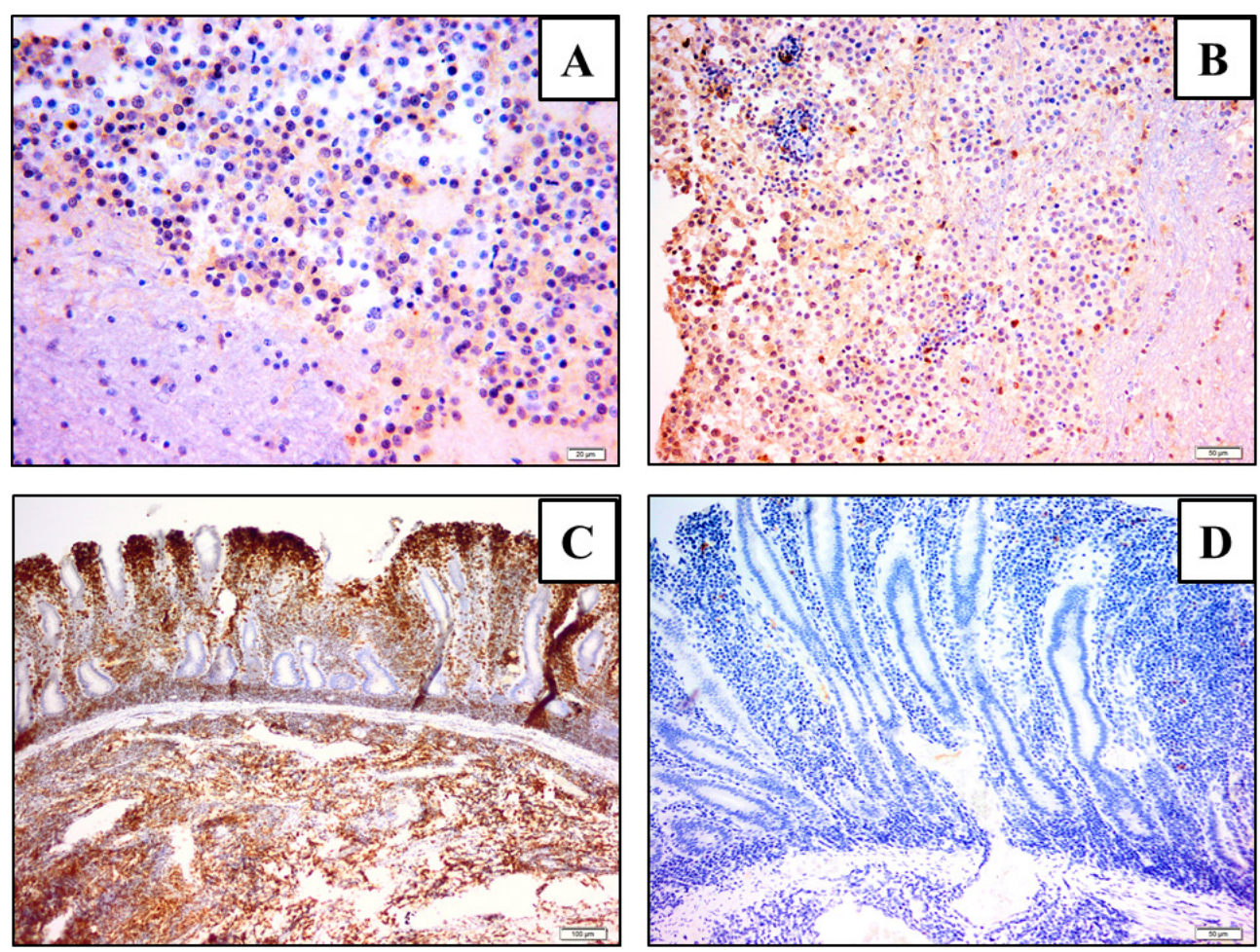

Fig. 4. Immunohistochemical aspects of digestive and primary central nervous system lymphoma. Primary central nervous system B-cell lymphoma: A, B- positive reaction for both CD79a and CD21 antibodies; Digestive T-cell lymphoma: C- positive reaction for CD3 antibody; D- negative reaction for CD20 antibody. 


\section{CONCLUSION}

In our paper, lymphomas were characterized depending on the immunophenotype into: B cell lymphomas (64.1\%), $\mathrm{T}$ cell lymphomas (33.34\%) and null type lymphomas (2.56\%). B cell lymphomas have prevailed in multicentric, mediastinal and primary central nervous system forms, while most of cutaneous and digestive lymphomas had $\mathrm{T}$ immunophenotype. Immunohistochemical description of canine lymphomas can deliver some major details concerning their behavior and malignancy.

To our knowledge, this is the first report on immunophenotyping of canine lymphomas, in our country. Vital prognosis and efficacy of some therapeutic protocols rely on the immunohistochemical features of canine lymphoma, thus helping the clinicians to obtain diagnostic certainty.

This research did not receive any specific grant from funding agencies in the public, commercial, or not-for-profit sectors.

\section{REFERENCES}

1. Affolter VK, Gross TL, Moore PF (2009). Indolent cutaneous T-cell lymphoma presenting as cutaneous lymphocytosis in dogs. Vet Dermatol, 20(5-6):577-585.

2. Baba AI, Cătoi C (2007). Comparative oncology. The Publishing House of Romanian Academy, 573-625.

3. Comazzi S, Gelain ME (2011). Use of flow cytometric immunophenotyping to refine the cytological diagnosis of canine lymphoma. Vet J, 188(2):149-155.

4. Coyle KA, Steinberg H (2004). Characterization of lymphocytes in canine gastrointestinal lymphoma. Vet Pathol, 41(2):141-146.

5. Day MJ (1995). Immunophenotypic characterization of cutaneous lymphoid neoplasia in the dog and cat. J Comp Pathol, 112(1):79-96.

6. Fournel-Fleury C, Magnol JP, Bricaire P, Marchal T, Chabanne L, Delverdier A, Bryon PA, Felman P (1997). Cytohistological and immunological classification of canine malignant lymphomas: comparison with human non-Hodgkin's lymphomas. J Comp Pathol, 117(1):35-59.

7. Fournel-Fleury C, Ponce F, Felman P, Blavier A, Bonnefont C, Chabanne L, Marchal T, Cadore JL, Goy-Thollot I, Ledieu D, Ghernati I (2002). Canine T-cell lymphomas: a morphological, immunological, and clinical study of 46 new cases. Vet Pathol, 39(1):92-109.

8. Fry MM, Vernau W, Pesavento PA, Brömel C, Moore PF (2003). Hepatosplenic lymphoma in a dog. Vet Pathol, 40(5):556-562.
9. Gelain ME, Mazzilli M, Riondato F, Marconato L, Comazzi S (2008). Aberrant phenotypes and quantitative antigen expression in different subtypes of canine lymphoma by flow cytometry. Vet Immunol Immunopathol, 121(3):179188.

10. Gibson D, Aubert I, Woods JP, Abrams-Ogg A, Kruth S, Wood RD, Bienzle D (2004). Flow cytometric immunophenotype of canine lymph node aspirates. J Vet Intern Med, 18(5):710-717.

11. Greenlee PG, Filippa DA, Quimby FW, Patnaik AK, Calvano SE, Matus RE, Kimmel M, Hurvitz AI, Lieberman PH (1990). Lymphomas in dogs a morphologic, immunologic, and clinical study. Cancer, 66(3):480-490.

12. Kiupel M, Teske E, Bostock D (1999). Prognostic factors for treated canine malignant lymphoma. Vet Pathol, 36(4):292-300.

13. Lana S, Plaza S, Hampe K, Burnett R, Avery AC (2006). Diagnosis of mediastinal masses in dogs by flow cytometry. J Vet Intern Med, 20(5):1161-1165.

14. Morrison WB (2004). Non-cutaneous lymphoma in the dog and cat, p. 3. In Morrison WB (Ed.). Lymphoma in dogs and cats. CRC Press, Jackson, Wyoming: Teton NewMedia, USA.

15. Ozaki K, Yamagami T, Nomura K, Narama I (2006). T-cell lymphoma with eosinophilic infiltration involving the intestinal tract in 11 dogs. Vet Pathol, 43(3):339-344.

16. Ponce F, Magnol JP, Marchal T, Chabanne L, Ledieu D, Bonnefont C, Felman P, Fournel-Fleury C (2003). High-grade canine T-cell lymphoma/leukemia with plasmacytoid morphology: a clinical pathological study of nine cases. J Vet Diagn Invest, 15(4):330-337.

17. Ponce F, Marchal T, Magnol JP, Turinelli V, Ledieu D, Bonnefont C, Pastor M, Delignette ML, Fournel-Fleury C (2010). A morphological study of 608 cases of canine malignant lymphoma in France with a focus on comparative similarities between canine and human lymphoma morphology. Vet Pathol, 47(3):414-433.

18. Rosol TJ, Capen CC (1992). Mechanisms of cancer-induced hypercalcemia. Lab Invest, 67(6):680-702.

19. Ruslander DA, Gebhard DH, Tompkins MB, Grindem CB, Page RL (1997). Immunophenotypic characterization of canine lymphoproliferative disorders. In vivo (Athens, Greece), 11(2):169-172.

20. Sisó S, Marco-Salazar P, Moore PF, Sturges BK, Vernau W, Wisner ER, Bollen AW, Dickinson PJ, Higgins RJ (2017). Canine Nervous System Lymphoma Subtypes Display Characteristic Neuroanatomical Patterns. Vet Pathol, 54(1):53-60.

21. Tasca S, Carli E, Caldin M, Menegazzo L, Furlanello T, Gallego LS (2009). Hematologic abnormalities and flow cytometric immunophenotyping results in dogs with hematopoietic neoplasia: 210 cases (2002-2006). Vet Clin Pathol, 38(1):2-12.

22. Teske E (1994). Canine malignant lymphoma: A review and comparison with human non-Hodgkin's lymphoma. Vet Q, 16(4):209-219.

23. Vail DM, Kisseberth WC, Obradovich JE, Moore FM, London CA, MacEwen EG, Ritter MA (1996). Assessment 
of potential doubling time (Tpot), argyrophilic nucleolar organizer regions (AgNOR), and proliferating cell nuclear antigen (PCNA) as predictors of therapy response in canine non-Hodgkin's lymphoma. Exp Hematol, 24(7):807-815.

24. Vail DM, Kravis LD, Kisseberth WC, Ogilvie GK, Volk LM (1997). Application of rapid CD3 immunophenotype analysis and argyrophilic nucleolar organizer region (AgNOR) frequency to fine needle aspirate specimens from dogs with lymphoma. Vet Clin Pathol, 26(2):66-70.

25. Vail DM, ME Pinkerton, KM Young (2013). Hematopoietic Tumors, Chapter 32, p. 608-678. In Withrow SJ, Page R, Vail DM (Eds.). Withrow and MacEwen's small animal clinical oncology. $5^{\text {th }}$ Edition, Elsevier Health Sciences.

26. Valli VE, Kass P, San Myint M, Scott F (2013), Canine lymphoma: The effect of age, stage of disease, subtype of tumor, mitotic rate and treatment protocol on overall survival. Vet Pathol 50:738-748.
27. Valli VEO, Bienzle D, Meuten DJ (2017). Tumors of the Hemolymphatic System, Chapter 7, p. 203-210. In Meuten DJ (Ed.). Tumors in Domestic Animals, $5^{\text {th }}$ Edition, John Wiley \& Sons, Inc., Wiley Blackwell, Iowa, USA.

28. Vezzali E, Parodi AL, Marcato PS, Bettini G (2010). Histopathologic classification of 171 cases of canine and feline non-Hodgkin lymphoma according to the WHO. Vet Comp Oncol, 8(1):38-49.

29. Vonderhaar MA, Morrison WB (2002). Lymphosarcoma, p. 641-670. In Morrison WB (Eds.). Cancer in Dogs and Cats: Medical and Surgical Management. $2^{\text {nd }}$ Edition, Jackson WY: Teton NewMedia.

30. Wilkerson MJ, Dolce K, Koopman T, Shuman W, Chun R, Garrett L, Barber L, Avery A (2005). Lineage differentiation of canine lymphoma/leukemias and aberrant expression of CD molecules. Vet Immunol Immunopathol, 106(3):179196. 